\title{
Pengaruh Penggunaan Media Video Terhadap Minat Dan Hasil Belajar Siswa Kelas Xi Pada Pelajaran Pai Di Sma Ypi Tunas Bangsa Palembang
}

Feri Ardiansah ${ }^{1}$

${ }^{1}$ STKIP Muhammadiyah Bangka Belitung

\begin{tabular}{ll}
\hline \hline Info Artikel : \\
\hline Diterima & $: 13$ Maret 2018 \\
Direvisi & $: 23$ Maret 2018 \\
Dipublish & $: 15$ April 2018
\end{tabular}

\section{Kata Kunci : \\ Media Video \\ Minat Belajar \\ Hasil Belajar}

\section{Keywords}

Media Video

Interests Learning

learning outcomes

\begin{abstract}
ABSTRAK
Penelitian ini bertujuan untuk menemukan ada tidaknya pengaruh video terhadap minat dan hasil belajar, serta untuk mengetahui hubungan minat belajar terhadap hasil belajar siswa. Metode yang digunakan dalam penelitian ini adalah true experimental design dengan desain Pretest-Posttest Control Group Design. Teknik pengambilan sampel dengan Cluster Random Sampling. Kelas eksperimen mendapat pembelajaran menggunakan media video, kelas kontrol tidak menggunakan media video. Teknik pengumpulan data dengan menggunakan angket dan tes. Untuk mengetahui pengaruh video terhadap minat belajar dalam penelitian ini menggunakan uji $t$, karena itu hasil uji signifikan secara statistik, dengan demikian kita dapat menolak hipotesis nol dimana tidak ada perbedaan rata-rata pengaruh video terhadap minat belajar kelompok eksperimen dan kelompok kontrol. Untuk pengaruh video terhadap hasil belajar menggunakan uji t, karena itu hasil uji signifikan secara statistik, dengan demikian kita dapat menerima hipotesis alternatif dimana ada perbedaan rata-rata hasil belajar kelompok eksperimen dan kelompok kontrol. Hasil uji hipotesis ketiga terdapat hubungan positif antara minat dan hasil belajar. Berdasarkan pembahasan, penulis menyarankan pada pihak sekolah agar mengupayakan melengkapi peralatan atau media untuk kelancaran proses pembelajaran, memotivasi guru-guru untuk meningkatkan kreativitas dalam menciptakan pembelajaran dan menyenangkan, hasil penelitian ini dapat di jadikan bahan pertimbangan untuk penelitian dimasa akan datang dalam mengembangkan dan memperluas lingkup media pembelajaran Pendidikan Agama Islam.
\end{abstract}

\section{ABSTRACT}

This research aims to find whether there is a video of the interests and influence learning outcomes, and to determine the relationship of interest in learning to student learning outcomes. The method used in this research is true experimental design with design pretest-posttest control group design. Cluster sampling technique with random sampling. Experimental class gets lesson using video media, media control class does not use video. Techniques of data collection using questionnaires and tests. To determine the effect of video on learning interest in this research using the $t$ test, because the test results are statistically significant, so we can reject the null hypothesis that there is no difference in the average video effect to the interest in studying the experimental group and the control group. For video effect on learning outcomes using t-test, because it tests the results are statistically significant, so we can accept the alternative hypothesis that there are differences in average learning outcomes experimental group and the control group. The third hypothesis test results there is a positive relationship between interest and learning outcomes. Based on the discussion, the authors recommend the school to strive to complete the equipment or media for the smooth process of learning, motivating teachers to improve learning and creativity in creating fun, the results of this research can be made in consideration for our future research in developing and expanding the scope of media learning Islamic education.

\section{Corresponding Author:}

Feri Ardiansah,

Email: Feri24ardiansyah@gmail.com 


\section{Pendahuluan}

Proses pembelajaran yang baik ditandai dengan adanya interaksi antara komponen dalam pembelajaran, dimana komponen-komponen yang berperan dalam suatu proses pembelajaran antara lain: guru, siswa, media, metode, perlengkapan, peralatan dan lingkungan kelas yang terarah pada tujuan pencapaian pembelajaran itu sendiri (Susilana, Si, \& Riyana, 2008). Proses pembelajaran pada hakikatnya adalah proses komunikasi, guru berperan sebagai pengantar dan siswa sebagai penerima pesan.(Susilana et al., 2008) Perkembangan teknologi telah mempengaruhi penggunaan berbagai jenis media, sebagai alat bantu dalam proses pembelajaran. Ada berbagai jenis dari media pembelajaran yang dapat dipergunakan di dalam proses pembelajaran diantaranya adalah media visual, media audio, media audio visual, dan multimedia (R Asyhar, 2011). Video merupakan bagian dari media audio visual. Dengan menguasai media-media pembelajaran yang populer tersebut, para guru dapat menempatkan dan memposisikan secara kreatif dalam rancangan pembelajaran yang menarik dan kreatif.

Video merupakan salah satu jenis media pembelajaran yang tergolong audio visual. Berikut ini adalah beberapa pendapat yang memberikan pengertian media video. Smaldino Lowther and Russel mengemukakan seperti ini: the term video to refer to electronic storage of moving images (videocassette, DVDs, computer-based video, and internet video (Putri \& Muhtadi, 2018). (Smaldino, Lowther, Russell, \& Mims, 2008) Sedangkan Arsyad mengemukakan seperti ini: video dapat menggambarkan suatu obyek yang bergerak bersama-sama dengan suara alamiah atau suara yang sesuai . (Dwy Rahayu, 2013) Pada halaman yang sama ia juga mengatakan: video melukiskan gambar hidup dan suara memberinya daya tarik sendiri." Pendapat lain yang tidak jauh berbeda dari dua pendapat di atas dikemukakan oleh Rahadi: video dapat menampilkan suara, gambar, dan gerakan sekaligus (Kusumadewi \& Suharto, 2010) . Umumnya media video berupa CD (compact disk). Berdasarkan ketiga pendapat di atas maka dapat disimpulkan bahwa media video merupakan gambar hidup atau bergerak yang disertai suara sekaligus.

Video menggambarkan suatu objek yang bergerak bersama-sama dengan suara alamiah atau suara yang sesuai. Kemampuan video melukiskan gambar hidup dan suara memberinya daya tarik tersendiri. Media ini umumnya digunakan untuk tujuan-tujuan hiburan, dokumentasi dan pendidikan. Video dapat menyajikan informasi, memaparkan proses, menjelaskan konsep-konsep yang rumit, mengajarkan keterampilan, menyingkat atau memperpanjang waktu dan mempengaruhi sikap. Gambar bergerak yang disertai dengan unsur suara dan dapat ditayangkan melalui medium video. Video memiliki beberapa features yang sangat bermanfaat untuk digunakan dalam proses pembelajaran. Salah satu features tersebut adalah slow motion dimana gerakan objek atau peristiwa tertentu yang berlangsung sangat cepat dapat diperlambat agar mudah dipelajari oleh siswa. Video dapat dipergunakan sebagai media untuk mempelajari objek dan mekanisme kerja dalam pelajaran di sekolah.

Menurut (Smaldino et al., 2008) lebih dari itu, manfaat dan karakteristik lain dari media video atau film dalam meningkatkan efektifitas dan efisiensi proses pembelajaran, di antaranya adalah: 1) mengatasi Jarak dan waktu; 2) mampu menggambarkan peristiwa-peristiwa masa lalu secara realistis dalam waktu yang singkat; 3) dapat membawa siswa berpetualang dari negara satu ke negara lainnya, dan dari masa yang satu ke masa yang lain; 4) dapat diulang-ulang bila perlu untuk menambah kejelasan; 5) pesan yang disampaikannya cepat dan mudah diingat; 6) mengembangkan pikiran dan pendapat para siswa; 7) mengembangkan imajinasi; 8) memperjelas hal-hal yang abstrak dan memberikan penjelasan yang lebih realistik; 9) mampu berperan sebagai media utama untuk mendokumentasikan realitas sosial yang akan dibedah di dalam kelas; 10) mampu berperan sebagai storyteller yang dapat memancing kreativitas peserta didik dalam mengekspresikan gagasannya.

Merujuk uraian tersebut dapat disimpulkan bahwa video adalah suatu media pembelajaran yang dirancang secara sistematis dengan berpedoman kepada kurikulum yang berlaku yang berisikan gambar bergerak yang disertai dengan suara yang berkaitan dengan pelajaran.Video adalah salah satu media pembelajaran yang dapat digunakan dalam pembelajaran PAI salah satunya Fikih, walaupun video memiliki kelemahan seperti kesulitan mendapatkan dan memproduksinya, namun media video memiliki keunggulan dibandingkan media lainnya dan sesuai untuk di gunakan dalam pembelajaran Fikih.

Minat merupakan suatu keadaan di mana seseorang mempunyai perhatian terhadap sesuatu dan disertai keinginan untuk mengetahui dan mempelajari maupun membuktikannya lebih lanjut. Minat timbul karena adanya perhatian yang mendalam terhadap suatu obyek, di mana perhatian tersebut menimbulkan keinginan untuk mengetahui, mempelajari, serta membuktikan lebih lanjut. Hal itu menunjukkan bahwa dalam minat, di samping perhatian juga terkandung suatu usaha untuk mendapatkan sesuatu dari obyek minat tersebut. 
Menurut Buchori minat adalah kesadaran seseorang, bahwa suatu objek, seseorang, suatu soal atau situasi mengandung sangkut paut dengan dirinya (Buchori, 1997). Jadi minat harus dipandang sebagai suatu sambutan yang sadar, kalau tidak demikian minat itu tidak memiliki arti sama sekali. Sardiman menyatakan, bahwa minat seseorang terhadap suatu obyek akan lebih kelihatan apabila obyek sasaran bekaitan dengan keinginan dan kebutuhan seseorang yang bersangkutan (Sardiman, 1988). Pendapat ini memberikan pengertian, bahwa minat merupakan suatu kondisi yang terjadi apabila berhubungan dengan keinginan atau kebutuhan sendiri, dengan kata lain ada kecenderungan apa yang dilihat dan diamati seseorang adalah sesuatu yang berhubungan dengan keinginan dan kebutuhan seseorang tersebut.

Pendapat lain mengatakan, bahwa minat adalah sebagai kecenderungan hati yang tinggi terhadap sesuatu; gairah; keinginan. Sedangkan Cony Semiawan dalam Paimun mengatakan, bahwa minat adalah suatu keadaan mental yang menghasilkan respons terarah kepada suatu situasi atau obyek tertentu yang menyenangkan dan memberikan kepuasan kepadanya (Paimun \& Etti, 1995). Dengan demikian, minat dapat menimbulkan sikap yang merupakan suatu kesiapan berbuat bila ada stimuli khusus sesuai dengan keadaan tersebut.

Pengertian minat tersebut dapat dipahami, bahwa seseorang menaruh minat terhadap suatu obyek karena adanya rangsangan, stimulus, atau dorongan. Rangsangan atau dorongan tersebut, dapat berasal dari kekuatan minat itu sendiri, sehingga dapat disimpulkan bahwa seseorang tidak dapat dikatakan mempunyai minat terhadap suatu obyek tanpa adanya respon atau dorongan terhadap obyek tersebut.

Minat merupakan sifat yang relatif menetap pada diri seseorang. Minat ini besar sekali pengaruhnya, dengan minat seseorang akan melakukan sesuatu yang diminatinya. Sebaliknya tanpa minat seseorang tidak mungkin melakukan sesuatu. Marshell dalam Usman mengemukakan 22 macam minat, salah satunya ialah bahwa anak memiliki minat terhadap belajar (Usman, 2009). Dengan demikian, pada hakikatnya setiap anak berminat pada belajar.

Minat merupakan penerimaan akan suatu hubungan yang terjadi dalam diri sendiri dengan sesuatu yang ada di luar diri. Minat merupakan modal yang besar untuk memperoleh benda atau tujuan yang diinginkannya. Menurut Muhibbin Syah, secara sederhana, minat (interest) berarti kecenderungan dan kegairahan yang tinggi atau keinginan yang besar terhadap sesuatu (Syah, 2003). Selain itu, Slameto (Djamarah, 2002) mengungkapkan, minat adalah suatu rasa lebih suka atau keterikatan pada suatu hal atau aktivitas tanpa ada yang menyuruh.

Dari pengertian-pengertian tersebut, maka dapat diambil kesimpulan bahwa minat belajar adalah rasa senang atau keterikatan terhadap materi pembelajaran yang terdapat pada diri peserta didik yang mendorongnya untuk mengikuti pembelajaran yang sedang atau akan berlangsung sehingga mewujudkan pembelajaran yang terarah.

Mengembangkan minat terhadap sesuatu pada dasarnya adalah membantu siswa melihat bagaimana hubungan antara materi yang diharapkan untuk dipelajari dengan dirinya sendiri sebagai individu, proses ini berarti menunjukkan pada siswa bagaimana pengetahuan atau kecakapan tertentu mempengaruhi dirinya, melayani tujuan-tujuannya, dan memuaskan kebutuhannya. Bila siswa menyadari bahwa belajar merupakan suatu alat untuk mencapai beberapa tujuan yang dianggapnya penting, dan jika siswa melihat bahwa hasil dari pengalaman belajarnya akan membawa kemajuan pada dirinya, kemungkinan besar ia akan berminat. Beberapa pendapat di atas menunjukkan adanya unsur perasaan senang yang menyertai minat seseorang.

Melihat beberapa pendapat dari para ahli tersebut, dapat diketahui ciri-ciri adanya minat pada seseorang dari beberapa hal, antara lain: adanya perasaan senang, adanya perhatian, dan adanya aktivitas yang merupakan akibat dari rasa senang dan perhatian.

1. Perasaan senang

Menurut (Ahmadi, 2009) perasaan senang adalah jiwa yang sedikit banyak bersifat subyektif dalam merasakan senang atau tidak senang. Menurut (Suryabrata, 2005), gejala psikis yang bersifat subyektif yang umumnya berhubungan dengan gejala-gejala mengenal dan dialami dalam kualitas senang atau tidak senang dalam berbagai taraf. Penilaian subyek terhadap sesuatu objek membentuk perasaan subyek yang bersangkutan. Artinya perasaan dapat timbul karena mengamati, menganggap, membayangkan, mengingat atau memikirkan sesuatu.

2. Perhatian

Menurut (Suryabrata, 2005), bahwa perhatian adalah pemusatan tenaga psikis tertuju kepada suatu obyek atau banyak sedikitnya kesadaran yang menyertai sesuatu aktivitas yang dilakukan. Menurut (Baharuddin, 2007) bahwa perhatian merupakan pemusatan atau konsentrasi dari seluruh aktivitas individu yang ditujukan kepada suatu sekumpulan objek. Dari beberapa pendapat di atas dapat disimpulkan bahwa perhatian merupakan pemusatan yang ditujukan kepada suatu objek. 


\section{Aktivitas}

Menurut (Suryabrata, 2005) bahwa aktivitas adalah banyak sedikitnya orang menyatakan diri, menjelmakan perasaan dan pikiran-pikirannya dalam tindakan yang spontan. Aktivitas dimaksud adalah keaktifan atau partisifasi langsung dalam suatu kegiatan. Sesuai dengan pendapat di atas, aktivitas merupakan prilaku yang aktif dalam melakukan tindakan yang merupakan penjelmaan dari perasaan.

\section{Pentingnya Minat Belajar Siswa}

Kondisi belajar mengajar yang efektif adalah adanya minat dan perhatian siswa dalam belajar. Kemudian (Usman, 2009) juga menyatakan, bahwa minat ini besar sekali pengaruhnya terhadap belajar, sebab dengan minat seseorang akan melakukan sesuatu yang diminatinya. Sebaliknya tanpa minat, seseorang tidak mungkin melakukan sesuatu.

Dari pernyataan tersebut, dapat dikatakan bahwa orang yang mempunyai minat terhadap sesuatu, ia akan berusaha lebih keras untuk memperoleh sesuatu yang diminatinya atau dengan kata lain dengan adanya minat dalam diri seseorang, maka ia akan termotivasi untuk mendapatkan sesuatu itu. Misalnya, seorang anak menaruh minat terhadap bidang olahraga sepak bola, maka ia akan berusaha untuk mempelajari dan mengetahui lebih banyak tentang olahraga sepak bola.

Dengan demikian, pada hakikatnya setiap anak berminat terhadap belajar, dan guru sendiri hendaknya berusaha membangkitkan minat anak terhadap belajar. Minat merupakan penerimaan akan suatu hubungan yang terjadi dalam diri sendiri dengan sesuatu yang ada di luar diri. Minat merupakan modal yang besar untuk memperoleh benda atau tujuan yang diinginkannya.

Menurut (Syah, 2003) secara sederhana, minat (interest) berarti kecenderungan dan kegairahan yang tinggi atau keinginan yang besar terhadap sesuatu. Selain itu,yang menjadi objek dari minat di sini adalah mengenai masalah belajar. Belajar adalah istilah kunci yang paling vital dalam setiap usaha pendidikan, sehingga tanpa adanya belajar sesungguhnya tak pernah ada pendidikan. Sebagai suatu proses, belajar hampir selalu mendapat tempat yang luas dalam berbagai disiplin ilmu yang berkaitan dengan upaya kependidikan. Karena itu, dengan belajar dapat mengarahkan dan memudahkan dalam tercapainya pemahaman bagi peserta didik.

Menurut Gagne (Dahar, 2011), belajar dapat didefinisikan sebagai suatu proses dimana suatu organisasi berubah perilakunya sebagai akibat pengalaman. Selanjutnya, Witherington (Purwanto, 1998) menyatakan bahwa, belajar adalah suatu perubahan di dalam kepribadian yang menyatakan diri sebagai suatu pola baru daripada reaksi yang berupa kecakapan, sikap, kebiasaan, kepandaian, atau suatu pengertian.

Dari pengertian-pengertian tersebut, maka dapat diambil kesimpulan bahwa minat belajar adalah rasa senang atau keterikatan terhadap materi pembelajaran yang terdapat pada diri peserta didik yang mendorongnya untuk mengikuti pembelajaran yang sedang atau akan berlangsung sehingga mewujudkan pembelajaran yang terarah.

\section{Pentingnya Peningkatan Minat Belajar Siswa}

Djamarah (Djamarah, 2002) mengemukakan bahwa, ada beberapa macam cara yang dapat meningkatkan minat peserta didik sebagai berikut:

1. membandingkan adanya suatu kebutuhan pada diri anak, sehingga dia rela belajar tanpa paksaan;

2. menghubungkan bahan pelajaran yang diberikan dengan persoalan pengalaman yag dimiliki anak didik, sehingga anak didik mudah menerima bahan pelajaran;

3. memberikan kesempatan kepada anak didik untuk mendapatkan hasil belajar yang baik dengan cara menyediakan lingkungan belajar yang kreatif dan kondusif.

Menggunakan berbagai bentuk dan teknik mengajar dalam konteks perbedaan individual anak didik Menurut (Dalyono, 2015) bahwa, minat dapat timbul karena daya tarik dari luar dan juga datang dari hati sanubari. Minat yang besar terhadap sesuatu merupakan modal yang besar artinya untuk mencapai/memperoleh benda atau tujuan yang diminati itu. Minat belajar yang besar cenderung menghasilkan prestasi yang tinggi.

Menurut Djamarah (Djamarah, 2002) bahwa, minat besar pengaruhnya terhadap aktifitas belajar. Anak didik yang berminat terhadap suatu mata pelajaran akan mempelajari dengan sungguh-sungguh, karena ada daya tarik baginya. Proses belajar akan berjalan dengan lancar bila disertai dengan minat. Minat merupakan alat motivasi yang utama yang dapat membangkitkan kegairahan belajar anak didik dalam kurun waktu tertentu. Melihat dari pendapat di atas, maka minat penting untuk ditingkatkan 
karena mempermudah proses belajar siswa dan untuk mencapai prestasi yang lebih tinggi dari sebelumnya.

\section{Faktor- faktor Yang Mempengaruhi Minat Belajar}

William James (Usman, 2009), menyatakan minat siswa merupakan faktor utama yang menentukan derajat keaktifan belajar siswa. Jadi, minat merupakan faktor yang menentukan keterlibatan siswa secara aktif dalam belajar. Selanjutnya Singer (Singer, 1987) mengemukakan beberapa faktor yang dapat menimbulkan minat terhadap pelajaran, sebagai berikut:

1. Pelajaran akan menarik murid jika terlihat adanya hubungan antara pelajaran dan kehidupan nyata;

2. Bantuan yang diberikan guru terhadap anak didiknya dalam mencapai tujuan tertentu;

3. Adanya kesempatan yang diberikan guru terhadap siswa untuk berperan aktif dalam proses belajar mengajar;

4. Sikap yang diperlihatkan guru dalam usaha meningkatkan minat siswa, sikap seorang guru yang tidak disukai oleh anak didik tentu akan mengurangi minat dan perhatian siswa terhadap mata pelajaran yang diajarkan oleh guru yang bersangkutan.

Singgih D. Gunarsa dan Ny. Y. Singgih Gunarsa (Gunarsa, n.d.) menyebutkan, bahwa minat akan timbul dari sesuatu yang telah diketahui, dan kita dapat mengetahui sesuatu dari belajar. Jadi, apabila seseorang belum pernah mendengar tentang sesuatu maka ia tidak akan menaruh minat terhadapnya. Minat tersebut, muncul dari sesuatu yang telah diketahui dan untuk mengetahui minat tersebut adalah melalui belajar.

Di samping itu, faktor lain yang dapat mempengaruhi timbulnya minat seseorang adalah adanya kesempatan. Hal ini, sebagaimana yang diungkapkan oleh Mappeira (Mappiare, 1983), bahwa minat akan muncul jika ada kesempatan untuk pemunculan minat tersebut. Sedangkan (Nasution, 2004) menyatakan, bahwa minat dapat ditimbulkan atau dibangkitkan dengan cara-cara sebagai berikut:

1. bangkitkan suatu kebutuhan (kebutuhan untuk menghargai keindahan, untuk mendapatkan penghargaan);

2. hubungan dengan pengalaman yang telah lalu;

3. beri kesempatan untuk mendapatkan hasil yang baik, "Nothing succed like succed", tak ada yang lebih memberi hasil yang baik daripada hasil yang baik. Untuk itu, bahan pelajaran harus sesuai dengan kesanggupan individu;

4. gunakan berbagai bentuk metode belajar seperti, diskusi, kerja kelompok, membaca, dan sebagainya.

Media pembelajaran menurut Kemp \& Dayton (Arsyad, 2013), dapat memenuhi tiga fungsi utama apabila media itu digunakan untuk perorangan, kelompok, atau kelompok pendengar yang besar jumlahnya, yaitu: (1) memotivasi minat atau tindakan, (2) menyajikan informasi, dan (3) memberi instruksi. Disamping itu penggunaan media pembelajaran dalam proses belajar mengajar juga dapat menumbuhkan minat belajar siswa. Hal ini sebagai mana yang dikatakan oleh Hamalik dalam Arsyad, yang mengemukakan bahwa, pemakaian media pembelajaran dalam proses belajar mengajar dapat membangkitkan keinginan dan minat yang baru, membangkitkan motivasi dan rangsangan kegiatan belajar, dan bahkan membawa pengaruh-pengaruh psikologis terhadap siswa.

Dengan bantuan media video materi-materi pembelajaran akan lebih mudah dipahami, karena media pembelajaran berupa video memiliki keunggulan atau kelebihan seperti yang telah diuraikan sebelumnya. Misalnya dengan media video siswa akan dapat mengetahui proses tata cara memandikan jenazah, atau memahami proses tata cara menguburkan jenazah. Dengan media video materi pembelajaran akan lebih mudah dipahami dan dapat menimbulkan minat belajar siswa. Oleh karena itu, perlu untuk melahirkan minat itu dengan perlakuan yang memotivasi dari informasi yang terkandung dalam media pembelajaran itu. (Arsyad, 2013)

Media pendidikan yang disebut audiovisual aids menurut Encyclopedia of Educational Research memiliki nilai diantaranya adalah sebagai berikut (Usman, 2009): dapat memperbesar perhatian siswa dan sangat menarik minat siswa dalam belajar. Video, sebagai media audio-visual yang menampilkan gerak, semakin lama semakin populer dalam masyarakat kita. Pesan yang disajikan bisa bersifat fakta (kejadian/peristiwa penting, berita) maupun fiktif (seperti misalnya ceritera), bisa bersifat informatif, edukatif maupun instruksional.(Sardiman, 1988)

Proses pembelajaran dengan menayangkan sebuah media video pembelajaran tentang suatu obyek, tentunya dapat membantu siswa dan guru dalam melaksanakan proses pembelajaran. Dalam suatu proses belajar mengajar, dua unsur yang sangat penting adalah metode mengajar dan media pembelajaran. Kedua unsur ini terlebih dahulu disesuaikan dengan materi yang hendak disampaikan. Keefektifan dan 
efisiensi dari media yang digunakan menjadi pertimbangan, dengan tetap memiliki tujuan agar siswa mendapatkan pengalaman belajar yang paling mendekati kongkret. Video dapat menjadi alat bantu pembelajaran yang ampuh bila digunakan secara efektif. Audio-visual/Media video dapat dimanfaatkan dalam pembelajaran yang menggunakan indera penglihatan dan indera pendengaran. Dengan demikian media video menjadi salah satu media alternatif untuk pembelajaran Fikih tentang tata cara pengurusan jenazah dalam rangka memudahkan siswa dalam memahami materi.

Dari uraian di atas jelas bahwa media video dapat menyentuh siswa baik secara fisik maupun secara psikis. Siswa akan tertarik dengan sajian mata pelajaran dengan menggunakan media video. Ketertarikan siswa terhadap media video berkaitan dengan keunggulan-keunggulan yang ada pada media video. Dengan tertarik pada media video ini akan dapat menjadikan siswa termotivasi dalam belajar dan diharapkan dapat meningkatkan minat belajar siswa.

Salah satu jenis tes adalah tes hasil belajar siswa, yaitu suatu tes yang berguna untuk membantu siswa untuk melihat kemajuan dirinya dan memudahkan guru dalam mengambil keputusan tentang rencana pembelajaran dan membantu sekolah menilai berbagai aspek kurikulum, yang menggambarkan kemajuan belajar siswa, (Hamalik, 1989). Tes juga merupakan alat ukur yang sering digunakan untuk mengukur keberhasilan siswa mencapai kompetensi, (Sanjaya, 2015).

Tes hasil belajar siswa dapat pula dikatakan sebagai suatu tes untuk mengukur dan menilai hasil belajar siswa dengan cara dan prosedur tertentu (Sudijono, 1998). Dari uraian di atas maka hasil belajar siswa adalah hasil belajar atau keadaan siswa setelah mengikuti proses pembelajaran tertentu dalam jangka waktu tertentu yang berupa perubahan prilaku baik kognitif, afektif maupun psikomotor.

Menurut (Sudjana, 2009), hasil belajar adalah suatu tindakan atau kegiatan untuk melihat sejauh mana tujuan-tujuan instruksional telah dapat dicapai atau dikuasai oleh peserta didik. Sedangkan menurut (widaningsih,2005) hasil belajar merupakan uraian untuk jawaban pertanyaan, Apa yang harus digali, dipahami, dan dikerjakan peserta didik. Selanjutnya menurut Abdurrahman (Abdurrahman, 2003) hasil belajar adalah kemampuan yang diperoleh anak setelah melalui kegiatan belajar.

Berdasarkan penjelasan tersebut, dapat disimpulkan bahwa hasil belajar adalah hasil yang dicapai oleh peserta didik setelah proses pembelajaran selesai untuk melihat sampai sejauhmana materi pembelajaran yang disampaikan guru dapat diterima oleh peserta didik.

Faktor Yang Mempengaruhi Hasil Belajar

Menurut Slameto (Slameto, 1988) faktor-faktor yang mempengaruhi hasil belajar siswa digolongkan menjadi dua, yaitu faktor intern dan faktor ekstern.

1. Faktor Intern

Faktor intern yang ada dalam diri siswa. Faktor intern dapat dikelompokkan, yaitu faktor jasmaniah, faktor psikologis dan faktor kelelahan.

a. Faktor Jasmaniah

Faktor jasmaniah meliput faktor kesehatan dan cacat tubuh. Proses kegiatan seseorang akan terganggu jika kesehatan seseorang terganggu, selain itu juga ia akan cepat lelah, kurang bersemangat, mudah pusing, ngantuk jika badannya lemah. Agar seseorang dapat belajar dengan baik, kesehatan badanya harus tetap terjamin.

Keadaan cacat tubuh mempengaruhi belajar. Siswa yang cacat belajarnya juga terganggu.

b. Faktor Psikologis

Faktor psikologis yang mempengaruhi hasil belajar siswa, yaitu intelegensi, perhatian, minat, bakat, motif, kematangan dan kesiapan. Faktor intelegensi atau kecerdasan merupakan salah satu faktor yang sangat besar pengaruhnya terhadap kemajuan belajar siswa. Siswa yang intelegensinya rendah, sulit untuk mencapai hasil belajar yang baik.

Menurut Hamalik (Hamalik, 1989), siswa yang memiliki tingkat kecerdasan yang tinggi umumnya memiliki perhatian yang lebih baik, belajar lebih cepat, kurang memerlukan latihan, mampu menyelesaikan pekerjaannya dalam waktu yang singkat, mampu menarik kesimpulan dan melakukan abstraksi. Sebaliknya siswa yang kurang cerdas menunjukkan ciri-ciri belajar lebih lambat, memerlukan banyak latihan, membutuhkan waktu yang lama untuk maju, tidak mampu melakukan abstraksi. Faktor Perhatian adalah pemusatan energi psikis yang tertuju kepada suatu objek pelajaran atau dapat dikatakan sebagai banyak sedikitnya kesadaran yang menyertai aktivitas belajar. (Sardiman, 1988)

Adanya perhatian siswa terhadap pelajaran yang dihadapi sangat penting untuk dapat menjamin hasil belajar yang baik. Bahan pelajaran yang tidak menarik perhatian siswa, akan membosankan. Karena bosan siswa tidak ingin belajar dan sebagai akibat, hasil belajarnya menjadi rendah atau menurun. Untuk menimbulkan perhatian diperlukan adanya suatu 
dorongan. Dalam hal ini orang tua siswa sangat diharapkan peranannya. Jika kebosanan terjadi di sekolah, maka guru dapat mengarahkan siswa untuk memperhatikan pelajaran. Minat belajar sebagai salah satu faktor yang mempengaruhi hasil belajar, memiliki pengaruh yang besar. Minat sangat besar pengaruhnya dalam mencapai hasil belajar dalam suatu pekerjaan tertentu.

Minat mengarahkan perbuatan kepada suatu tujuan dan merupakan pendorong bagi perbuatan itu. Dalam diri manusia terdapat motif-motif yang mendorong manusia untuk berinteraksi dengan dunia luar. Menurut Purwanto (Purwanto, 1998), bahwa apa saja yang menarik minat seseorang maka akan mendorongnya untuk berbuat lebih giat dan lebih baik. Jika bahan yang dipelajari siswa sesuai dengan bakatnya, maka hasil belajarnya lebih baik karena ia senang belajar dan pastilah selanjutnya ia lebih giat lagi dalam belajar.

Motif yang kuat sangat diperlukan dalam belajar. Untuk membentuk motif yang kuat dapat dilaksanakan dengan adanya latihan-latihan serta adanya pengaruh lingkungan yang memperkuat, jadi latihan sangat perlu dalam belajar. Karena bosan siswa tidak ingin belajar dan sebagai akibat, hasil belajarnya menjadi rendah atau menurun. Untuk menimbulkan perhatian diperlukan adanya suatu dorongan

c. Faktor kelelahan

Kelelahan mempengaruhi hasil belajar, agar siswa dapat belajar dengan baik haruslah menghindari jangan sampai terjadi kelelahan dalam belajar.

2. Faktor Ekstern

Faktor ekstern adalah faktor yang ada di luar diri siswa. Faktor ekstern dikelompokkan menjadi tiga faktor yaitu : faktor keluarga, faktor sekolah dan faktor masyarakat.

Lingkungan keluarga adalah lingkungan yang paling dekat dalam kehidupan siswa. Salah satu faktor penentu dalam keluarga adalah orang tua. Orang tua harus dapat menciptakan suatu keadaan dimana anak berkembang dalam suasana ramah tamah, kejujuran dan kerjasama yang diperlihatkan oleh masing-masing anggota keluarga dalam hidup mereka setiap hari. Faktor yang sangat mempengaruhi hasil belajar anak dalam keluarga, meliputi cara mendidik, hubungan orang tua dengan anak dan ekonomi keluarga.

Sekolah sebagai tempat dimana siswa menuntut ilmu juga ikut menentukan hasil belajar siswa. Hubungan siswa dengan guru, hubungan siswa dengan siswa lain, kurikulum serta metode pembelajaran yang digunakan sangat menentukan hasil belajar siswa tersebut. Masalah-masalah yang ada di sekolah dan kurang menarik bagi siswa akan mengurangi minat belajar siswa di sekolah sehingga hasil belajar yang diperoleh tidak akan maksimal.

Kehidupan masyarakat di sekitar siswa juga ikut berpengaruh terhadap hasil belajar siswa. Jika masyarakat di sekitar siswa melakukan kebiasaan yang tidak baik, akan berpengaruh jelek pada siswa yang ada di lingkungan itu. Akibatnya belajarnya terganggu dan bahkan siswa kehilangan semangat belajar. Sebaliknya jika lingkungan siswa adalah orang yang baik-baik, siswa terpengaruh ke hal-hal baik. Pengaruh itu dapat mendorong siswa untuk belajar lebih giat, dan hasil belajar yang diperoleh akan baik.

Seorang guru harus mampu menciptakan suasana belajar mengajar yang kondusif, guru menciptakan suasana yang kondusif misalnya dengan memilih media pengajaran yang sesuai dengan materi pelajaran yang diajarkan. Guru dalam menyampaikan materi terkadang memerlukan suatu contoh yang komplek untuk ditampilkan pada siswa, disini akan terasa kesulitannya maka video dapat menggantikan obyek yang terlalu besar ataupun yang terlalu kecil kedalam bentuk gambar, film,atau model sehingga ini dapat mengatasi keterbatasan ruang, waktu dan daya indera. Misalnya dalam mempelajari hidrokarbon yang bersifat abstrak, dengan menggunakan media audio visual yang berbasis Video, guru dapat memaparkan bentuk 2 dimensi dan 3 dimensi dari senyawa-senyawa hidrokarbon. Dengan begitu siswa dapat tertarik untuk belajar dengan adanya penggunaan media yang sesuai dengan materi pelajaran yang pada akhirnya dapat mempengaruhi hasil belajar siswa.

Seorang guru harus mampu menciptakan suasana belajar mengajar yang kondusif, guru menciptakan suasana yang kondusif misalnya dengan memilih media pengajaran yang sesuai dengan materi pelajaran yang diajarkan. Media pembelajaran dapat memperjelas penyajian pesan dan informasi sehingga dapat memperlancar dan meningkatkan proses dan hasil belajar.(Arsyad, 2013)

Sudjana dalam (Djamarah \& Zain, 2006), Penggunaan media dalam pengajaran diutamakan untuk mempertinggi mutu belajar mengajar. Dengan perkataan lain, menggunakan media, hasil belajar yang dicapai siswa akan tahan lama diingat siswa, sehingga mempunyai nilai yang tinggi. Dalam pembelajaran agama islam, siswa dapat langsung melihat proses materi melalui video yang ditayangkan. Penggunaan media, baik itu transparansi OHP, film, video ataupun gambar dalam proses belajar mengajar, perlu diberikan sejumlah pedoman seperti mengkaji apakah tujuan instruksional dapat dicapai atau tidak pada 
akhir kegiatan. Kegiatan belajar anak didik dengan bantuan media akan menghasilkan proses dan hasil belajar yang lebih baik daripada tanpa bantuan media. (Djamarah \& Zain, 2006) Media video dapat dimanfaatkan untuk kegiatan belajar mengajar sehingga dapat meningkatkan hasil belajar.

Penggunaan media pandang dapat diartikan sebagai penggunaan alat dan bahan ajaran khusus untuk komunikasi seperti buku, majalah, globe, peta, majalah dinding, film, film strip, TV, radio, recorder, gambar grafik, model, demonstrasi, dan lain-lain. Penggunaan yang lebih luas dari alat-alat tersebut akan memiliki keuntungan sebagai berikut (Djamarah \& Zain, 2006):

1. Membantu secara konkret konsep berpikir, dan mengurangi respon yang kurang bermanfaat.

2. Memiliki secara potensial perhatian anak didik pada tingkat yang tinggi.

3. Dapat membuat hasil belajar yang riil yang akan mendorong kegiatan mandiri anak didik.

4. Mengembangkan cara berpikir berkesinambungan, seperti halnya dalam film.

5. Memberi pengalaman yang tidak mudah dicapai oleh alat yang lain.

6. Menambah frekuensi kerja, lebih dalam, dan variasi belajar.

Guru dalam menyampaikan materi terkadang memerlukan suatu contoh yang komplek untuk ditampilkan pada siswa, disini akan terasa kesulitannya maka video dapat menggantikan obyek yang terlalu besar ataupun yang terlalu kecil kedalam bentuk gambar, film, atau model sehingga ini dapat mengatasi keterbatasan ruang, waktu dan daya indera. Sebagian besar tugas film dapat digantikan oleh video. Tapi tidak berarti bahwa video akan menggantikan kedudukan film.(Arief, 2010) Misalnya dalam mempelajari tata cara pengurusan jenazah yang bersifat abstrak, dengan menggunakan media audio visual yang berbasis Video, guru dapat memperlihatkan secara langsung bagaimana tata cara memandikan, mengafani, menyalatkan, dan menguburkan jenazah. Dengan begitu siswa dapat tertarik untuk belajar dengan adanya penggunaan media yang sesuai dengan materi pelajaran yang pada akhirnya dapat mempengaruhi hasil belajar siswa.

Secara sederhana, minat (interest) berarti kecenderungan dan kegairahan yang tinggi atau keinginan yang besar terhadap sesuatu. Minat seperti yang dipahami dan dipakai orang selama ini dapat mempengaruhi kualitas pencapaian hasil belajar siswa dalam bidang-bidang studi tertentu.(Syah, 2003) Umpamanya, seorang siswa yang menaruh minat besar terhadap PAI akan memusatkan perhatiannya lebih banyak dari pada siswa lainnya. Hasil belajar berdasarkan teori di atas, jelaslah bagi kita bahwa minat dapat berperan sebagai pendorong bagi siswa untuk memperoleh hasil yang baik. Dalam hal ini siswa yang mempunyai minat yang kuat dalam belajar dapat dikenali dari perhatian, kemauan dan konsentrasi.

Menurut Slameto (Slameto, 1988), belajar lebih berhasil bila berhubungan dengan minat, keinginan dan tujuan siswa. Peran serta yang ditimbulkan karena adanya minat dapat mempengaruhi aktivitas belajarnya yang pada akhirnya merupakan suatu usaha untuk mencapai hasil belajar yang maksimal. Sehingga dapat dikatakan bahwa minat belajar berhubungan dengan hasil belajar siswa pada mata pelajaran PAI. Karena semakin tinggi minat belajar siswa, maka akan semakin tinggi pula gairah belajarnya, selanjutnya akan memperbesar usaha belajar siswa, sehingga pada akhirnya semakin tinggi pula hasil belajar yang dicapai siswa terrsebut. Jadi minat terhadap sesuatu merupakan hasil belajar dan menyokong belajar selanjutnya. Walaupun minat terhadap sesuatu hal tidak merupakan hal yang hakiki untuk dapat mempelajari hal tersebut, asumsi umum menyatakan bahwa minat akan membantu seseorang mempelajarinya. (Slameto, 1988)

Kondisi belajar mengajar yang efektif adalah adanya minat dan perhatian siswa dalam belajar. Oleh karena itu guru dihadapkan terutama dengan penemuan minat sesudah diperoleh pada suatu tingkat belajar, sehingga dia dapat merencanakan pelajarannya untuk menemukan tingkat perbedaan perhatianperhatian yang timbul dari pengalaman-pengalaman.

Lebih jauh untuk merencanakan sedemikian rupa bimbingannya dalam belajar dimana dia menghendaki mungkinnya tiap-tiap pelajar untuk mengembangkan minatnya terhadap apa yang tengah dipelajarinya. James dalam bukunya (Usman, 2009) melihat bahwa, minat siswa merupakan faktor utama yang menentukan derajat keaktifan belajar siswa.

Mengingat pentingnya minat dalam belajar, seorang tokoh pendidikan dari belgia, yakni Declory dalam Usman mendasarkan sistem pendidikannya pada pusat minat anak. (Usman, 2009) Mursell dalam bukunya Successful Teaching, memberikan suatu klasifikasi yang berguna bagi guru dalam memberikan pelajaran kepada siswanya. Ia mengemukakan 22 macam minat yang diantaranya ialah bahwa anak memiliki minat terhadap belajar. Dengan demikian, pada hakikatnya setiap anak berminat terhadap belajar, dan guru sendiri hendaknya berusaha membangkitkan minat anak terhadap belajar. (Usman, 2009) Hubungan penggunaan media video dengan Minat dan Hasil Belajar sesuai dengan nilai-nilai praktis pembelajaran menurut diantaranya adalah, dengan media dapat meletakkan dasar-dasar yang 
nyata untuk berpikir, karena dapat mengurangi verbalisme, dan media dapat memperbesar minat dan perhatian peserta didik untuk belajar serta media dapat meletakkan dasar untuk perkembangan belajar sehingga hasil belajar bertambah mantap. (Djamarah \& Zain, 2006) Pada dasarnya media pembelajaran dan minat belajar memiliki kaitan yang erat dalam proses pembelajaran. Media pembelajaran yang dimaksud dalam penelitian ini adalah media video.

Dari uraian tersebut itu pula dapat disimpulkan bahwa belajar dapat dipengaruhi oleh minat, metode mengajar serta media yang digunakan. Dengan kata lain penggunaan media video dapat berpengaruh terhadap minat belajar dan hasil belajar siswa.

Materi pelajaran Pendidikan Agama Islam (PAI) pada kompetensi menjelaskan tatacara pengurusan jenazah akan membahas bagaimana memandikan,mengafani, menyalatkan dan menguburkan jenazah. Kegiatan pembelajaran tersebut secara lisan sulit untuk di ingat dan di pahami, maka seharusnya dalam penyampaian materi dipilih metode pembelajaran yang benar-benar tepat agar semua pesan yang ingin disampaikan guru dapat diterima secara total oleh siswa.

Berdasarkan studi pendahuluan melalui wawancara informal penulis dengan guru mata pelajaran Pendidikan Agama Islam (PAI) di SMA YPI Tunas Bangsa Palembang, diketahui bahwa selama ini pembelajaran hanya menggunakan metode konvensional. Pada mata pelajaran PAI selama ini hanya menggunakan papan tulis, gambar yang dibuat secara manual dan ceramah saja. Sehingga siswa tidak mengerti terhadap pelajaran yang telah disampaikan dalam proses belajar mengajar. Dalam hal inilah pada saat mengikuti proses belajar mengajar mengakibatkan siswa kurang berminat dan siswa kebanyakan tidak fokus seperti mengantuk, lesu, dan kurang memperhatikan penjelasan yang diberikan oleh guru. Hal ini menyebabkan hasil belajar siswa pada pelajaran Pendidikan Agama Islam (PAI) rendah.

Oleh karena itu dalam pembelajaran PAI perlu digunakan media pembelajaran yang dapat meningkatkan minat dan hasil belajar siswa. Salah satunya dengan menggunakan media video. Hal ini sesuai dengan hasil penelitian yang dilakukan oleh Harmadi (2010), yaitu Pengaruh Penggunaan Media Video terhadap Motivasi dan Hasil Belajar Siswa dalam Pembelajaran Ilmu Pengetahuan Sosial di SMP Negeri 2 Lais Musi Banyu Asin menyatakan ada pengaruh penggunaan media video terhadap motivasi dan hasil belajar siswa.

Penelitian ini bertujuan untuk menemukan ada tidaknya pengaruh video terhadap minat dan hasil belajar, serta untuk mengetahui hubungan minat terhadap hasil belajar siswa.

\section{Metode}

Metode yang digunakan dalam penelitian ini adalah metode true experimental design dengan desain Pretest-Posttest Control Group Design, yaitu pada desain ini kelas eksperimen dan kelas kontrol dipilih secara random. Desain ini dapat dilihat dalam gambar 1:

\begin{tabular}{|llll|}
\hline $\mathrm{R} 1$ & $\mathrm{O}_{1}$ & $\mathrm{X}$ & $\mathrm{O}_{2}$ \\
$\mathrm{R} 2$ & $\mathrm{O}_{3}$ & - & $\mathrm{O}_{4}$ \\
\hline
\end{tabular}

Gambar 1: Desain Penelitian

Dimana O1 adalah nilai Pretest kelas eksperimen, O2 adalah nilai posttest kelas eksperimen, O3 adalah nilai pretest kelas kontrol O4 adalah Nilai posttest kelas kontrol dan $\mathrm{X}$ adalah Perlakuan (treatment), yaitu berupa penggunaan media video.

Pada penelitian ini menggunakan teknik sampel cluster (Cluster Random Sampling). Menurut Darmadi pemilihan sampel cluster adalah pemilihan sampel dimana yang dipilih secara random bukan individual, tetapi kelompok-kelompok. (Darmadi, 2013) Cluster random sampling adalah cara pengambilan sampel secara random (acak) yang didasarkan pada kelompok atau kelas, tidak didasarkan anggotaanggotanya. sembilan kelas/kelompok tersebut memiliki kemampuan yang hampir sama, sehingga pemilihan kelas eksperimen dan kelas kontrol dilakukan dengan cara diundi, tidak didasarkan pada pertimbangan yang lain.

Kelompok eksperimen menggunakan media video sedangkan kelompok kontrol tidak menggunakan media video. Sebelum diberikan perlakuan, masing-masing kelompok diberikan pre-test terlebih dahulu yang dilanjutkan dengan pemberian perlakuan penggunaan media video pada kelas eksperimen dan media powerpoint pada kelas kontrol. Selanjutnya masing-masing kelas kemudian diberikan post-test untuk melihat hasil dari perlakuan. 
Dalam penelitian ini yang menjadi populasinya adalah seluruh siswa kelas XI SMA YPI Tunas Bangsa Palembang yang berjumlah 387 siswa. Untuk Sampel 100 siswa dengan rincian, kelompok eksperimen 50 siswa dan kelompok kontrol 50 siswa. Teknik pengumpulan data dalam penelitian ini adalah menggunakan instrumen angket dan tes hasil belajar. Untuk pengolahan data menggunakan SPSS 16. Uji Hipotesis dengan menggunakan Uji t dan Analisa Regresi Sederhana.

\section{Hasil dan Pembahasan}

\section{Deskripsi Pelaksanaan Penelitian}

Penelitian ini berlangsung selama 4 kali pertemuan dengan materi "Pengurusan Jenazah". Penelitian melakukan uji coba instrument di kelas XI IPA1 dengan siswa berjumlah 47 orang di tempat yang sama. Pertemuan pertama dilakukan pretest dikelas eksperimen dan kelas kontrol, pertemuan keempat dilakukan post test untuk melihat hasil belajar siswa kelas eksperimen dan kelas kontrol.

\section{Uji Normalitas dan Homogenitas}

Untuk mengetahui apakah sebaran data mempunyai sebaran normal atau tidak secara analitik yaitu dengan menggunakan uji Kolmogorov Smirnov. Dalam penelitian ini jumlah sampel 100, untuk kelompok eksperimen berjumlah 50 siswa dan kelompok kontrol berjumlah 50 siswa. Hasil uji normalitas angket minat terdapat pada tabel 1 berikut :

Tabel 1. Normalitas Data Angket Minat

\begin{tabular}{|c|c|c|c|}
\hline \multirow{2}{*}{$\begin{array}{l}\text { Angket } \\
\text { minat }\end{array}$} & \multicolumn{3}{|c|}{ Kolmogorov-Smirnov ${ }^{a}$} \\
\hline & Statistic & $\overline{D f}$ & $p$-value \\
\hline ksperime & 0.115 & 50 & 0.095 \\
\hline Kontrol & 0.118 & 50 & 0.080 \\
\hline
\end{tabular}

\section{a. Lilliefors Significance Correction}

\section{Sumber : Data diolah dari SPSS 16}

Pada tabel 1 di atas diperoleh data angket minat belajar untuk kelas eksperimen signifikansi $p$-value $=$ $0,095,>0,05$, sehingga $p$-value $>\alpha$ dengan demikian data berdistribusi normal. Sedangkan untuk kelas kontrol diperoleh signifikansi $\mathrm{p}$-value $=0,080,>0,05$. sehingga $\mathrm{p}$-value $>\alpha$ dengan demikian data berdistribusi normal.

Dan adapun hasil uji normalitas tes hasil belajar terdapat pada tabel 2 berikut :

Tabel 2. Normalitas Data Hasil Belajar

\begin{tabular}{lccc} 
Hasil belajar & \multicolumn{3}{c}{ Kolmogorov-Smirnov } \\
\cline { 2 - 4 } & Statistic & Df & p-value \\
Eksperimen & 0.110 & 50 & 0.185 \\
Kontrol & 0.113 & 50 & 0.153 \\
\hline
\end{tabular}

Pada tabel 2 di atas diperoleh data hasil belajar untuk kelas eksperimen signifikansi $p$-value $=0,110$, $>0,05$, sehingga $p$-value $>\alpha$ dengan demikian data berdistribusi normal. Sedangkan untuk kelas kontrol diperoleh signifikansi $p$-value $=0,113,>0,05$. sehingga $p$-value $>\alpha$ dengan demikian data berdistribusi normal.

Sedangkan hasil uji homogenitas data angket minat dan tes hasil belajar kelas eksperimen dan kelas kontrol terdapat pada tabel 3 berikut :

Tabel 3. Homogenitas Data

\begin{tabular}{lll} 
Variabel & $\begin{array}{l}\text { Signifikansi } \\
\text { Uji F }\end{array}$ & Keterangan \\
\hline Minat Belajar & 0,966 & Homogen \\
Hasil Belajar & 0,448 & Homogen \\
\hline
\end{tabular}

Dari tabel 3 tersebut, diperoleh signifikansi dari uji $\mathrm{F}$ untuk Minat belajar didapat 0,966 dan hasil belajar didapat 0,448 . Karena nilai signifikansi $>0,05$, maka Ho ditolak. Jadi dapat disimpulkan bahwa kelompok data minat dan hasil belajar antara kelas eksperimen dan kelas kontrol memiliki varian yang sama.

\section{Uji Hipotesis}


Hipotesis penelitian ini diuji dengan teknik Independent Sample $T$ Test untuk hipotesis 1 dan 2, sedangkan untuk hipotesis 3 diuji dengan regresi sederhana.

Uji t ini digunakan untuk melihat ada tidaknya pengaruh media video (X) terhadap minat (Y1) dan hasil belajar (Y2). Apabila nilai $t_{\text {hitung }} \geq t_{\text {tabel }}$ maka Ho ditolak, apabila $t_{\text {hitung }}<t_{\text {tabel }}$, maka Ho diterima. Dengan derajat kebebasan $(\mathrm{dk})=98$ pada taraf signifikansi $5 \%(\alpha=0,05)$.

Dalam penelitian ini ada satu variabel independent (media video) yang di uji pengaruhnya terhadap dua variabel dependen yaitu minat belajar dan hasil belajar siswa pada kedua kelas baik kelas eksperimen maupun kelas kontrol dengan menggunakan perhitungan SPSS versi 16 sebagai berikut:

Hasil Uji Hipotesis 1

Untuk menguji hipotesis 1 , pengaruh penggunaan media video terhadap minat belajar adalah sebagai berikut: Jika $t_{\text {hitung }} \geq t_{\text {tabel }}$, maka Ho ditolak dan Ha diterima dan Jika $t_{\text {hitung }}<t_{\text {tabel }}$, maka Ho diterima dan Ha ditolak

Pada uji t minat belajar siswa dapat kita lihat pada Tabel 4 sebagai berikut:

Tabel 4. Hasil Uji Independent Samples T Test Minat Belajar

Minat Levene's Test for Equality of Variances

\begin{tabular}{|c|c|c|c|c|}
\hline & $\mathrm{F}$ & Sig. & $\overline{\mathrm{T}}$ & $\overline{\mathrm{Df}}$ \\
\hline Equal variances assumed & 7.035 & $\begin{array}{c}.00 \\
9\end{array}$ & $\begin{array}{c}15.35 \\
3\end{array}$ & 98 \\
\hline $\begin{array}{l}\text { Equal variances not } \\
\text { assumed }\end{array}$ & & & $\begin{array}{c}15.35 \\
3\end{array}$ & 88.505 \\
\hline
\end{tabular}

Dari Tabel 4 diketahui nilai $t_{\text {hitung }}$ adalah 15,353 dan signifikan $0,009 . \mathrm{t}_{\text {tabel }}$ pada signifikansi $0,05: 2$ $=0,025$ (uji 2 sisi) dengan derajat kebebasan (df) $\mathrm{n}-2$ atau $100-2=98$. Hasil yang diperoleh untuk $\mathrm{t}_{\text {tabel }}$ sebesar 1,984. Kriteria pengujian sebagai berikut: Jika $t_{\text {hitung }} \leq t_{\text {tabel, }}$, maka Ho diterima dan Jika $t_{\text {hitung }}>t_{\text {tabel }}$, maka Ho ditolak.

Berdasar signifikansi: Jika signifikansi $>0,05$, maka Ho diterima Jika signifikansi $<0,05$, maka Ho ditolak.

Karena nilai $\mathrm{t}_{\text {hitung }}>\mathrm{t}_{\text {tabel }}(15,353>1,984)$ dan signifikansi $<0,05(0,009>0,05)$ maka Ho ditolak. Jadi dapat disimpulkan bahwa ada perbedaan rata-rata nilai minat antara kelas kontrol dengan kelas eksperimen. Dari perhitungan SPSS dapat pula diketahui bahwa rata-rata nilai minat kelas eksperimen lebih tinggi. Hal ini dapat diartikan bahwa adanya perlakuan memberikan andil dalam peningkatan minat belajar siswa.

Dilihat dari mean (rerata) gain score minat belajar, diketahui bahwa rerata kelas eksperimen lebih tinggi dibandingkan rerata kelas kontrol. Perbedaan mean gain score minat belajar antara kelas kontrol dan kelas eksperimen dapat dilihat pada Tabel 5 berikut:

Tabel 5. Mean Gain Score Minat Belajar

\begin{tabular}{ll} 
Kelompok & Mean Gain Score \\
\hline Eksperimen & 12,2800 \\
Kontrol & 4,7800 \\
\hline
\end{tabular}

Berdasarkan Tabel 5 tersebut, dapat disimpulkan bahwa ada pengaruh signifikan penggunaan media video dalam pembelajaran PAI terhadap minat belajar siswa kelas XI di SMA YPI Tunas Bangsa Pal embang.

\section{Hasil Uji Hipotesis 2}

Pada uji t hasil belajar siswa kelas eksperimen dapat dilihat pada tabel 6 sebagai berikut:

Tabel 6. Hasil Uji Independent Samples T Test Hasil Belajar

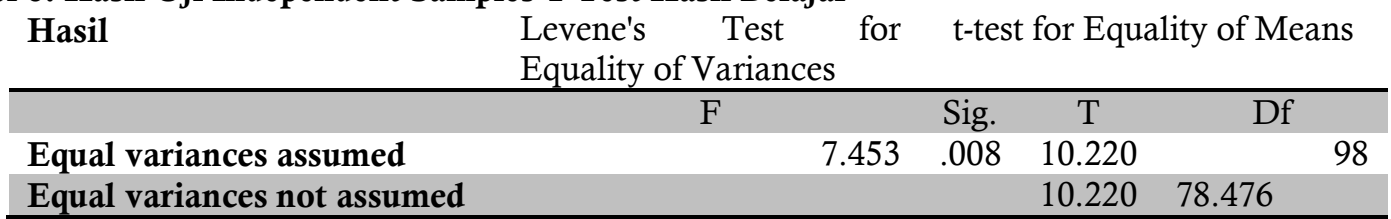

Dari Tabel 6 tersebut, diketahui nilai $t_{\text {hitung }}$ adalah 10,220 dan signifikansi 0,008 . $t_{\text {tabel }}$ pada signifikansi $0,05: 2=0,025$ (uji 2 sisi) dengan derajat kebebasan (df) $n-2$ atau $100-2=98$. Hasil yang diperoleh untuk $t_{\text {tabel }}$ sebesar 1,984 kriteria pengujian sebagai berikut: Jika $-t_{\text {hitung }} \leq t_{\text {tabel }}$, maka Ho diterima dan Jika $-t_{\text {hitung }}>t_{\text {tabel }}$, maka Ho ditolak. 
Berdasar signifikan: Jika signifikansi $>0,05$, maka Ho diterima dan Jika signifikansi $<0,05$, maka Ho ditolak.

Karena nilai $t_{\text {hitung }}>t_{\text {tabel }}(10,220>1,984)$ dan signifikansi $<0,05(0,008<0,05)$ maka Ho ditolak. Jadi dapat disimpulkan bahwa ada perbedaan rata-rata nilai hasil belajar antara kelas kontrol dan kelas eksperimen. Dari perhitungan SPSS dapat pula diketahui bahwa rata-rata nilai hasil belajar kelas eksperimen lebih tinggi. Hal ini dapat diartikan bahwa adanya perlakuan memberikan andil dalam peningkatan hasil belajar siswa.

Dilihat dari mean (rerata) gain score hasil belajar, diketahui bahwa rerata kelas eksperimen lebih tinggi dibandingkan rerata kelas kontrol. Perbedaan mean gain score hasil belajar antara kelas kontrol dan kelas eksperimen dapat dilihat pada Tabel 7 berikut:

\section{Tabel 7. Mean Gain Score Hasil Belajar}

\begin{tabular}{ll} 
Kelompok & Mean Gain Score \\
\hline Eksperimen & 19,1372 \\
Kontrol & 8,8800 \\
\hline
\end{tabular}

Berdasarkan Tabel 7 tersebut, dapat disimpulkan bahwa ada pengaruh signifikan penggunaan media video pada pelajaran PAI terhadap hasil belajar siswa kelas XI di SMA YPI Tunas Bangsa Palembang.

\section{Hasil Uji Hipotesis 3}

Untuk menguji hipotesis 3 , hubungan antara minat dan hasil belajar siswa dengan penggunaan media video pada pelajaran PAI menggunakan analisis regresi dengan program SPSS versi 16 seperti pada Tabel 8 berikut:

Tabel 8. Hasil Uji Regresi Minat dan Hasil belajar Model Summary ${ }^{\mathbf{b}}$

\begin{tabular}{|l|l|l|l|l|}
\hline $\begin{array}{l}\text { Mode } \\
1\end{array}$ & $R$ & R Square & $\begin{array}{l}\text { Adjusted } \\
\text { R Square }\end{array}$ & Std. Error of the Estimate \\
\hline 1 & $.868^{\mathrm{a}}$ & .753 & .748 & 1.82060 \\
\hline
\end{tabular}

Tabel 9. Output Coefficients Uji Regresi Coefficients $^{\mathrm{a}}$

\begin{tabular}{|c|c|c|c|c|c|}
\hline \multirow[b]{2}{*}{ Model } & \multicolumn{2}{|c|}{$\begin{array}{l}\text { Unstandardized } \\
\text { Coefficients }\end{array}$} & \multirow{2}{*}{\begin{tabular}{|l}
$\quad \begin{array}{r}\text { Standardized } \\
\text { Coefficients }\end{array}$ \\
Beta \\
\end{tabular}} & \multirow[b]{2}{*}{$\mathrm{T}$} & \multirow[b]{2}{*}{ Sig. } \\
\hline & B & Std. Error & & & \\
\hline $1 \quad$ (Constant) & 5.102 & 1.164 & & 4.384 & .000 \\
\hline Minat belajar & 1.117 & .092 & .868 & 12.087 & .000 \\
\hline
\end{tabular}

Dependent Variable: hasil belajar

Dari Tabel 8 tersebut, diketahui nilai $\mathrm{R}$ yaitu korelasi antara variabel minat dan hasil belajar sebesar 0,868 . Hal ini berarti terjadi hubungan positif yang sangat erat, karena nilai mendekati 1 . Sedangkan nilai $\mathrm{R}^{2}$ sebesar 0,753 , artinya presentase sumbangan pengaruh variabel minat terhadap hasil belajar sebesar $75 \%$, sedangkan sisanya sebesar $25 \%$ dipengaruhi oleh variabel lain. Nilai-nilai pada output kemudian dimasukkan ke dalam persamaan regresi sebagai berikut: $\mathrm{Y}=5,102+1,117$ Arti angka-angka pada persamaan tersebut adalah sebagai berikut: Nilai konstanta (a) adalah 5,102; artinya jika minat bernilai 5 (lima), maka hasil belajar bernilai positif, yaitu 5,102. Nilai koefisien regresi variabel minat (b) bernilai positif, yaitu 1,117; ini dapat diartikan bahwa setiap peningkatan minat sebesar 1 poin, maka hasil belajar juga akan meningkat sebesar 1,117.

Dari Tabel 9 tersebut, diketahui nilai $t_{\text {hitung }}$ sebesar 12,087, jika dibandingkan dengan $t_{\text {tabel }}$ pada signifikansi $0,05 / 2=0,025$ dengan derajat kebebasan $\mathrm{df}=\mathrm{n}-2$ yaitu $50-2=48$. Hasil yang diperoleh untuk $t_{\text {tabel }}$ sebesar 2,011, karena nilai $t_{\text {hitung }}>t_{\text {tabel }}(12,087>2,011)$ dan signifikansi $<0,05(0,000<0,05)$ maka Ho ditolak. Jadi dapat disimpulkan bahwa minat berpengaruh terhadap hasil belajar secara signifikan pada taraf kepercayaan $95 \%$. 


\section{Pembahasan}

\section{Pengaruh Penggunaan Media Video Terhadap Minat Belajar Siswa}

Untuk melihat pengaruh penggunaan media video terhadap minat dan hasil belajar, dari hasil perlakuan dalam penelitian dapat dilihat dari presentase siswa dari kelas yang menggunakan media video (kelas eksperimen) dan kelas yang tidak menggunakan media video (kelas kontrol). Untuk kelas yang menggunakan media video, presentase minat belajar siswanya lebih tinggi dibandingkan dengan siswa pada kelas yang tidak menggunakan media video.

Pengaruh penggunaan media video dilihat dari kategori minat belajar berdasarkan tabel 17 menunjukkan bahwa dengan penggunaan media video, didapat nilai minat siswa pada kelas eksperimen kategori : sangat tinggi (2\%), dan tinggi (98\%), sedangkan Minat siswa pada kelas yang tidak menggunakan media video (kelas kontrol) yaitu minat sangat tinggi (0), tinggi (98\%) dan cukup tinggi $(2 \%)$.

Hasil penelitian ini membuktikan bahwa penggunaan media video berpengaruh signifikan terhadap minat belajar siswa. Sejalan dengan pendapat Arsyad (Arsyad, 2013), mengemukakan bahwa pemakaian media pembelajaran dalam proses belajar mengajar dapat membangkitkan keinginan dan minat yang baru, membangkitkan motivasi dan rangsangan kegiatan belajar, dan bahkan membawa pengaruh-pengaruh psikologis terhadap siswa. Dengan media pembelajaran siswa dapat melihat dan mendengar pesan-pesan yang disampaikan guru dibandingkan dengan tanpa media.

Menurut Midun (Rayandra Asyhar, 2012) menyatakan bahwa, media pembelajaran dapat menambah kemenarikan tampilan sehingga meningkatkan motivasi dan minat serta mengambil perhatian peserta didik untuk fokus mengikuti materi yang disajikan, sehingga diharapkan efektifitas belajar meningkat pula.

Guru tidak hanya menyediakan kondisi seperti mengatur proses, mengatur kegiatan belajar mengajar atau membantu siswa dalam mengembangkan keinginannya, tetapi juga motivator dan fasilitator dalam pembelajaran. Sebagai fasilitator, guru menyediakan fasilitas berupa media untuk membelajarkan siswa tentang suatu proses dan menjelaskan fenomena yang ada. Hal ini terbukti bahwa minat belajar siswa meningkat dengan penggunaan media video.

\section{Pengaruh Penggunaan Media Video Terhadap Hasil Belajar Siswa}

Dari Tabel 6 dapat dilihat bahwa penggunaan media video mempengaruhi hasil belajar siswa pada kelas eksperimen karena nilai $t_{\text {hitung }}>t_{\text {tabel }}(10,220>1,984)$ dan signifikansi $<0,05(0,008<0,05)$ maka Ho ditolak. Jadi dapat disimpulkan bahwa ada perbedaan rata-rata nilai hasil belajar antara sebelum dan sesudah perlakuan. Untuk kelas yang menggunakan media video, persentase hasil belajar siswanya lebih tinggi dibandingkan dengan siswa pada kelas yang tidak menggunakan media video, dapat dilihat pada Tabel 18 menunjukkan bahwa hasil belajar siswa pada kelas menggunakan media video sangat baik (18\%), baik (62\%), dan cukup (20\%), sedangkan hasil belajar siswa pada kelas yang tidak menggunakan media video kategori sangat baik (8\%), baik (48\%), cukup (38\%), dan kurang (6\%).

Hasil penelitian ini membuktikan bahwa penggunaan media video berpengaruh signifikan terhadap hasil belajar siswa. Hal ini seperti yang diutarakan oleh Miarso (Miarso, 2004), bahwa penggunaan media pembelajaran dapat meningkatkan motivasi belajar siswa yang pada gilirannya dapat meningkatkan hasil belajar siswa. Kualitas pembelajaran memerlukan berbagai upaya untuk mewujudkannya. Upaya tersebut dengan berbagai komponen yang terlibat di dalam pembelajaran, salah satu diantaranya adalah dengan pemanfaatan media pembelajaran. Hal ini sesuai dengan hasil penelitian Felton, et al dalam (Rayandra Asyhar, 2012)menunjukkan bahwa penggunaan media dalam proses pembelajaran secara signifikan mampu meningkatkan pencapaian hasil belajar.

Dari uraian tersebut, ternyata bahwa guru yang mampu mengupayakan aktivitas siswa berupa minat akan berdampak terhadap meningkatnya hasil belajar siswa. Dalam hal ini berbagai jenis minat dalam mempelajari materi PAI akan lebih berhasil apabila didukung oleh peran guru bagaimana mendesain pembelajaran yang bisa menumbuhkan atau memperkuat minat tersebut. Sebagaimana hasil dari penelitian ini dengan menggunakan media video, suatu media yang banyak digemari siswa agar siswa lebih aktif dalam proses pembelajaran, didapatkan bahwa minat belajar siswa kelas eksperimen meningkat dan terlihat berdampak pula terhadap meningkatnya hasil belajar yang di raih setiap siswa. 


\section{Hubungan Minat Dan Hasil Belajar}

Berdasarkan tabel 15 Hasil variabel Y1 (Minat Belajar ) dengan Y2 (Hasil Belajar) di peroleh R sebesar 0,868 yang artinya korelasi antara variabel minat dan hasil belajar memiliki hubungan positif yang sangat erat, karena nilai mendekati 1 . Hal ini berarti hubungan minat belajar terhadap hasil belajar menunjukan hubungan yang positif, maka Ha di terima dan Ho di tolak artinya signifikan.

\section{Kesimpulan}

Berdasarkan hasil analisa data dan pembahasan pada penelitian ini dapat disimpulkan sebagai berikut ;

1. Terdapat pengaruh penggunaan media video terhadap minat belajar siswa kelas XI pada pelajaran PAI di SMA YPI Tunas Bangsa Palembang dengan menggunakan uji t. Dilihat dari tabel 11 diketahui nilai $\mathrm{t}_{\text {hitung }}$ adalah 15,353 dan signifikan 0,009. $\mathrm{t}_{\text {tabel }}$ pada signifikansi $0,05: 2=0,025$ (uji 2 sisi) dengan derajat kebebasan (df) $n-2$ atau $100-2=98$. Hasil yang diperoleh untuk $t_{\text {tabel }}$ sebesar 1,984. Karena nilai $t_{\text {hitung }}>t_{\text {tabel }}(15,353>1,984)$ dan signifikansi $<0,05(0,009>0,05)$ maka Ho ditolak. Jadi dapat disimpulkan bahwa ada perbedaan rata-rata nilai minat antara kelas kontrol dengan kelas eksperimen.

2. Terdapat pengaruh penggunaan media video terhadap hasil belajar kelas XI pada pelajaran PAI di SMA YPI Tunas Bangsa Palembang. Dilihat dari Tabel 13, diketahui nilai $t_{\text {hitung }}$ adalah 10,220 dan signifikansi 0,008 . $t_{\text {tabel }}$ pada signifikansi $0,05: 2=0,025$ (uji 2 sisi) dengan derajat kebebasan (df) $n-2$ atau $100-2=98$. Hasil yang diperoleh untuk $t_{\text {tabel }}$ sebesar 1,984 . Karena nilai $t_{\text {hitung }}>t_{\text {tabel }}(10,220>$ $1,984)$ dan signifikansi $<0,05(0,008<0,05)$ maka Ho ditolak. Jadi dapat disimpulkan bahwa ada perbedaan rata-rata nilai hasil belajar antara kelas kontrol dan kelas eksperimen;

3. Terdapat hubungan positif antara minat dan hasil belajar siswa kelas XI pada pelajaran PAI di SMA YPI Tunas Bangsa Palembang. Dilihat dari Tabel 15, diketahui nilai $\mathrm{R}$ yaitu korelasi antara variabel minat dan hasil belajar sebesar 0,868 . Hal ini berarti terjadi hubungan positif yang sangat erat, karena nilai mendekati 1 . Sedangkan nilai $\mathrm{R}^{2}$ sebesar 0,753 , artinya presentase sumbangan pengaruh variabel minat terhadap hasil belajar sebesar $75 \%$, sedangkan sisanya sebesar $25 \%$ dipengaruhi oleh variabel lain.

\section{REFERENSI}

Abdurrahman, M. (2003). Pendidikan bagi anak berkesulitan belajar. Jakarta: Rineka Cipta.

Ahmadi, A. (2009). Psikologi umum. Jakarta: Rineka Cipta.

Arief, S. (2010). dkk. Media Pendidikan pengertian, pengembangan dan pemanfaatnya. Jakarta: Raja Grafindo Persada.

Arsyad, A. (2013). Media pembelajaran edisi revisi. Jakarta: Rajawali Pers.

Asyhar, R. (2011). Kreatif Mengembangkan Media Pembelajaran (Jakarta. Gaung Persada Press.

Asyhar, R. (2012). Kreatif mengembangkan media pembelajaran. Jakarta: Referensi Jakarta.

Baharuddin, H. (2007). Psikologi pendidikan: Refleksi teoritis terhadap fenomena. Yogyakarta: Ar-Ruzz Media.

Buchori, M. (1997). Pengantar Psikologi Pendidikan. Jakarta: Jermare.

Dahar, R. W. (2011). Teori-teori belajar dan pembelajaran. Jakarta: Erlangga, 136, 141.

Dalyono, M. (2015). Psikologi Pendidikan, cetakan 8. Jakarta: Rineka Cipta.

Darmadi, H. (2013). Metode penelitian pendidikan dan sosial. Bandung: Alfabeta.

Djamarah, S. B. (2002). Psikologi belajar. Jakarta: Rineka Cipta.

Djamarah, S. B., \& Zain, A. (2006). Strategi belajar mengajar. Jakarta: Rineka Cipta.

Dwy Rahayu, R. (2013). Pengaruh penggunaan video kartun mencampur warna terhadap kemampuan kognitif pada anak kelompok $\mathrm{b}$ di tk terpadu al-hidayah ii ds. Bakung kec. Udanawu kab. Blitar. PAUD Teratai, 2(2). 
Gunarsa, S. D. G. (n.d.). Ny. Y Singgih D. Psikologi Keperawatan.

Hamalik, U. (1989). Teknik pengukuran dan evaluasi pendidikan. Mandar Maju.

Kusumadewi, L. F., \& Suharto, S. (2010). Peningkatan Hasil Belajar Seni Musik dengan Media Audio Visual melalui Metode Bervariasi. Harmonia: Journal Of Arts Research And Education, 10(2).

Mappiare, A. (1983). Psikologi orang dewasa bagi penyesuaian dan pendidikan. Usaha Nasional.

Miarso, Y. (2004). Menyemai benih teknologi pendidikan. Kencana.

Nasution, S. (2004). Didaktik Azas-Azas Mengajar, cet 3, Jakarta: PT. Bumi Aksara.

Paimun, H., \& Etti, K. (1995). Psikologi Perkembangan. Jakarta: DEPAG.

Purwanto, M. N. (1998). Psikologi Pendidikan, cet. 13, Bandung: PT. Remaja Rosdakarya.

Putri, D. P. E., \& Muhtadi, A. (2018). Pengembangan multimedia pembelajaran interaktif kimia berbasis android menggunakan prinsip mayer pada materi laju reaksi. Jurnal Inovasi Teknologi Pendidikan, 5(1), 38-47.

Sanjaya, W. (2015). Perencanaan dan desain sistem pembelajaran. Kencana.

Sardiman, A. M. (1988). Interaksi dalam proses belajar mengajar. Jakarta: Rajawali Press.

Singer, K. (1987). Membina Hasrat Belajar di Sekolah,(Terj. Bergman Sitorus). Bandung: Remaja Rosda Karya.

Slameto. (1988). Belajar dan Faktor-faktor yang Mempengaruhinya. Bina Aksara.

Smaldino, S. E., Lowther, D. L., Russell, J. D., \& Mims, C. (2008). Instructional technology and media for learning.

Sudijono, A. (1998). Pengantar evaluasi pendidikan. PT RajaGrafindo.

Sudjana, N. (2009). Penilaian Hasil Belajar Proses Belajar Mengajar. Bandung: PT Remaja Rosdakarya.

Suryabrata, S. (2005). Psikologi pendidikan. PT Rajagrafindo.

Susilana, R., Si, M., \& Riyana, C. (2008). Media pembelajaran: hakikat, pengembangan, pemanfaatan, dan penilaian. CV. Wacana Prima.

Syah, M. (2003). Psikologi belajar. PT Rajagrafindo Persada.

Usman, M. (2009). Uzer, Menjadi Guru Profesional, Cet. XIII (Bandung: PP. Remaja Rosda Karya, 2001). 